\title{
In memoriam Professor Janusz Jerzy Pysiak (1933-2017)
}

\author{
Barbara Pacewska ${ }^{1}$
}

Received: 7 April 2017/ Accepted: 7 April 2017/Published online: 19 April 2017

(C) The Author(s) 2017. This article is an open access publication

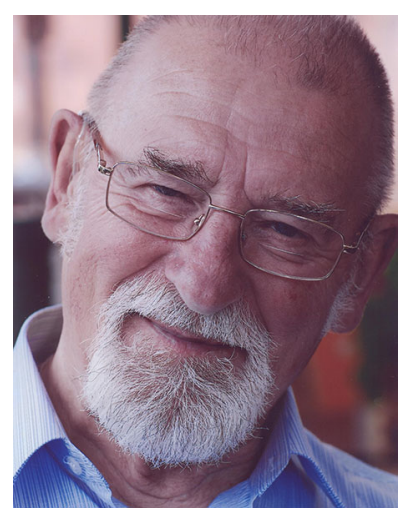

Professor Janusz Jerzy Pysiak, an outstanding Polish scientist, a specialist in chemistry and an university lecturer passed away on 4th February 2017 at the age of 84 . We lost our teacher, a very experienced researcher and a dear colleague.

Professor Pysiak was born in 1933 in Vilnius where he spent the first years of his life. He studied in the Faculty of Chemistry at the Warsaw University of Technology, and he subsequently spent most of his professional life at the Warsaw University of Technology, first as professor's assistant (1958) and finally as professor (1988).

In 1958, he became an assistant to Professor Stanisław Bretsznajder, a great Polish specialist in chemical technology, creator of innovative technologies. Working under the supervision of Professor Stanisław Bretsznajder, he had a unique opportunity to develop not only his research

Barbara Pacewska

Barbara.Pacewska@pw.edu.pl

1 Institute of Chemistry, Warsaw University of Technology, Łukasiewicza 17 St., 09-400 Płock, Poland interests but also, very importantly, his practical experience of experimental installations and pilot plants in industry.

In 1970, he became an academic staff member of the Płock branch of the Warsaw University of Technology, and he was the main co-founder of the present Institute of Chemistry at this University. During the next nearly 35 years of his work in Płock, he held various positions of responsibility, e.g. he was the Vice-dean of the Faculty of Civil and Mechanical Engineering and he was for many years the Director of the Institute of Chemistry. He was also the organizer and the Head of the Department of General Chemistry, from 1972 until his retirement that took place in 2004.

The real passion of Professor Pysiak was his scientific work. His wide range of scientific interests included inorganic chemistry and solid-state physicochemistry. From the beginning of his scientific work, he was interested in the thermal analysis and thermal decomposition of solids. One of the most important scientific achievements of Professor Pysiak was the innovative and in-depth studies of the mechanisms and kinetics of the thermal decomposition of solids, difficult and not fully known research problems. Often, he performed his research work as part of international programs. At the turn of 1968 and 1969, he held a scientific internship in the Soviet Union, where he personally worked with Professor M.M. Pawluczenko (Institute of General and Inorganic Chemistry of the Academy of Sciences of the Belarussian S.S.R., Minsk), Professor S.Z. Rogiński (Institute of Chemical Physics of Russian Academy of Sciences, Moscow) and Professor W.W. Boldyriew (Institute of Chemical Kinetics and Combustion of Academy of Science USSR, Novosibirsk).

Professor Pysiak has a lot of scientific achievements, among them nearly 100 original papers mostly published in international journals, a few chapters of monographs (3 
published in abroad), 10 patents in different fields, about 150 publications in conference materials and also several dozen projects prepared for industry. He was a member of Scientific Committee and author of selected entries in Encyklopedia Fizyki (in Polish), PWN, Warsaw, vol. 1-3, 1972-1974. He was also repeatedly invited to be a member of scientific committees of conferences where he frequently presented his research results also as distinctive lectures.

Professor Pysiak was a great propagator of science, especially in the fields of thermal analysis. It is worthwhile to emphasize the fact that he was the initiator and organizer of the cycles of scientific seminars, devoted to memory of Professor St. Bretsznajder. The first seminar took place in 1977, and until 2002, Professor Pysiak acted as the Chairman of the Scientific Committee of these seminars. These scientific events from the beginning were very successful and attracted many scientists, not only from Poland but also from other countries. These seminars have gained a place in the calendar of important scientific events devoted to issues related to thermal analysis and calorimetry in Poland and abroad. These conferences are now perceived as regular, international scientific events with English as the obligatory language and are organized in Płock. The selected works presented at these seminars, after peer review, are published in the special issues of Journal of Thermal Analysis and Calorimetry. Professor Pysiak was a Guest Editor or Co-editor of some of the parts of those special issues.

Professor Pysiak was one of the founders of the Polish Society of Calorimetry and Thermal Analysis (PTKAT). Until 1994, he was an active member of the Board of this society. For his contribution in the development of the PTKAT and for his services for the development of thermal analysis and calorimetry in Poland, he was awarded the title of the Honorary Member of PTKAT and the Wojciech Świętosławski Medal. He was also very active in other scientific societies. Among others, he was the founder and many years' chairman (1972-1996) of the Polish Chemical Society-Płock Division and the vice-president of the Płock Scientific Society. Since 1988, he was a member of the International Confederation for Thermal Analysis and Calorimetry (ICTAC). The results of Professor Pysiak's investigations are known worldwide, and in recognition of his achievements in the field of thermal analysis, he was invited to present his CV in both issues of "Who is who in thermal analysis and calorimetry", published in 2004 by the Kiado Academy in Budapest and by the Springer Publishers in 2014.

Professor Pysiak with great passion explained the complex topics of general and inorganic chemistry to students. He was a respected teacher, educator and authority for several generations of young people. He was the academic adviser to numerous students (MSc and PhD dissertations). Professor Pysiak often reviewed doctor's and habilitation theses (also from abroad) and a lot of scientific papers submitted for publication in different journals.

The achievements of Professor Pysiak were noticed and appreciated within many fields of his activity. He received many scientific and didactic awards, also important national distinctions.

Professor Pysiak's life, however, consisted not only of his professional work. He also found time to develop his hobbies. He was a passionate photography enthusiast, lover of numismatics and mountain walker. Until the age of 38, he practiced climbing. He was a member of a number of photography-related societies. For many years, he engaged in photography for his own pleasure; however, since 1995 he has displayed his works publicly at various types of individual and collective exhibitions in Poland and abroad.

4th February 2017 is the day when the great man with a great and colourful biography passed away. He carried out all aspects of his activities to full perfection. He left his contribution in scientific life, above all in the form of his scientific works for the next generations of chemists. He has left a large number of wonderful photographs displaying the world as seen through his eyes.

He will remain in our memory for ever.

Open Access This article is distributed under the terms of the Creative Commons Attribution 4.0 International License (http://crea tivecommons.org/licenses/by/4.0/), which permits unrestricted use, distribution, and reproduction in any medium, provided you give appropriate credit to the original author(s) and the source, provide a link to the Creative Commons license, and indicate if changes were made. 